\title{
MENGGESER PARADIGMA KONTRA TERHADAP KRIMINALISASI PEMERKOSAAN DALAM RUMAH TANGGA
}

\author{
Riskyanti Juniver Siburian
}

The Master's Programme in Law, Faculty Of Law, Universitas Indonesia Jl. Salemba Raya No. 4, Kec. Senen, Kota Jakarta Pusat, DKI Jakarta, 10430. Telp. (021)31909008.Fax. (021)39899148Riskyantijuniver@gmail.com

Submitted :13/10/2019 Reviewed: 28/01/2020 Accepted: 31/03/2020

\begin{abstract}
Marital rape is an act of threat or violence that compels another person to do sexual intercourse where there's a marital relation between the offender and the victim. Marital rape is considered as taboo which results to pros and cons as the government is on the process to criminalize such act. The aims of this research are to bring up how the acceptance of marriage as part of sexual violence (rape) develop based on Indonesia's criminal law, and to confront theoretical and juridical basis of the acceptance. This research was conducted by using normative-juridical method. This research shows: (1) At first, Indonesia's criminal law didn't recognize such act as rape as mentioned in Article 284 KUHP. Article 46 jo. Article 8 section e UU-PKDRT and Article 16 jo. Article 11 section (2) subsection e RUU-PKS then arise as the contender which makes it possible to punish such act; (2) The initial of accepting the criminalization of marital rape is the emerge offeminist thought contradicting the 'old-fashioned perspective' about "contract-of-marriage" that gives husband the "right to sex", the thought that wife is "property" of the husband, and critical feminism criminology which mentioned that women in marital relation are more vunerable as being a victim. Government's reaction is needed to criminalize such act as it contradicts Article 28G UUD RI 1945.
\end{abstract}

Keywords: Marital Rape; Criminal Act; Rancangan Undang-Undang Penghapusan Kekerasan Seksual

Abstrak: Marital Rape adalah pemaksaan hubungan seksual dalam rumah tangga,
di mana antara pelaku dan korban terdapat ikatan perkawinan. Isu marital rape
dianggap tabu sehingga muncul pro-kontra mengenai intervensi negara dalam
mengkriminalisasi perbuatan sebagaimana dimaksud. Tujuan penelitian adalah
untuk mengetahui perkembangan unsur perkawinan sebagai bagian tindak pidana
pemaksaan hubungan seksual (perkosaan) berdasarkan hukum pidana materiil di 
Indonesia serta untuk mengetahui dasar teoritis dan yuridis penerimaan kriminalisasi marital rape. Metode penelitian adalah yuridis-normatif. Hasil penelitian menunjukkan (1) Pada awalnya hukum pidana Indonesia tidak memaknai pemaksaan hubungan seksual pada korban dan pelaku yang memiliki ikatan perkawinan sebagai perkosaan (Pasal 284 KUHP). Muatan mengenai pemaksaan hubungan seksual dalam ranah perkawinan mulai diatur sebagai tindak pidana dalamPasal 46 jo. Pasal 8 huruf a UU-PKDRT dan Rancangan Undang-Undang Penghapusan Kekerasan Seksual. (2) Penerimaan kriminalisasi marital rape diawali munculnya pemikiran feminist yang menggeser perspektif lama mengenai anggapan perempuan harus memenuhi "right to sex" suami akibat adanya contract of marriage, pandangan istri adalah "hak milik" (property) suami, serta perspektif critical feminism criminology yang menyebutkan wanita dalam ikatan perkawinan cenderung menjadi korban kejahatan. Negara perlu memberikan perlindungan melalui sanksi pidana karena pemaksaan hubungan seksual dalam bentuk apapun menyalahi hak asasi sebagaimana dimaksud Pasal 28G UUD RI 1945.

Kata Kunci: Marital Rape; Tindak Pidana; Rancangan Undang-Undang Penghapusan Kekerasan Seksual.

\section{PENDAHULUAN}

Sejak tahun 2014, Indonesia dinyatakan darurat kekerasan seksual oleh Komnas Perempuan sehingga membutuhkan suatu ketentuan hukum yang secara khusus menanggulangi keadaan tersebut ${ }^{1}$. Ketentuan yang kemudian dituangkan ke dalam Rancangan Undang-Undang Penghapusan Kekerasan Seksual (RUU-PKS) tersebut masuk ke dalam program legislasi nasioal (prolegnas). Nyatanya hingga bulan Agustus 2019, Rancangan undang-undang tersebut belum disahkan, padahal awalnya pengesahan dijadwalkan sebelum Pemilihan Umum $2019^{2}$.. Yang terjadi justru munculnya polemik dalam masyarakat,

1 Friski Riana. 2018. Darurat Kekerasan Seksual dan Pembahasan RUU-PKS yang Lambat. https://nasional.tempo.co/read/1149125/daruratkekerasan-seksual-dan-pembahasan-RUU-PKSyang-lambat, diakses pada16 Agustus 2019.

2 CNN Indonesia. 2019. Pemerintah Targetakn RUU-PKS Disahkan Agustus 2019. https://www.cnnindonesia.com/ nasional/20190222200631-20-371945/ terutama terkait ketentuan pidana yang dapat dikenakan kepada pelaku perkosaan dalam ranah rumah tangga (marital rape). Sebagian masyarakat setuju dengan keputusan negara untuk menjatuhkan sanksi pidana terhadap pelaku marital rape, dan sebgian lagi secara keras menolak ketentuan tersebut.

Apabila melihat jumlah kasus pada tahun 2018, kasus terkait hubungan seksual dengan cara yang tidak diinginkan dan menyebabkan penderitaan terhadap isteri (marital rape) mencapai 195 kasus $^{3}$. Jumlah tersebut meningkat dari tahun 2017 yang mencapai 172 kasus $^{4}$, dan tahun 2016 yang mencapai 135

pemerintah-targetkan-RUU-PKS-disahkanagustus-2019, diakses pada 16 Agustus 2019.

3 Komnas Perempuan. 2019. Catatan Tahunan Tentang Kekerasan Terhadap Perempuan Tahun 2018, hlm. 14.

4 Komnas Perempuan. 2018. Catatan Tahunan Tentang Kekerasan Terhadap Perempuan 2017, hlm. 14. 
kasus ${ }^{5}$. Sedangkan ditahun 2015 ke bawah tidak tercantum secara kongkrit jumlah kasus marital rape dalam Catatan Tahunan Komnas Perempuan 2017 yang didasarkan pada alasan perceraian yang tercatat pada Pengadilan Agama ${ }^{6}$. Hal ini dikarenakan perkosaan dalam rumah tangga yang tergolong kedalam kekerasan seksual belum diakui oleh Pengadilan Agama dan dimasukkan ke dalam terminologi "lain-lain". Padahal, mengutip dari tulisan dalam Catatan Tahunan (Catahu) Komnas Perempuan Tahun 2017, penghalusan terminology yang dilakukan tersebut "mengaburkan fenomena yang sesungguhnya tentang jenis kekerasan terhadap perempuan yang diproses." 7

Kata perkosaan berasal dari bahasa latin "rapere", yang berarti mencuri, memaksa, merampas, atau membawa pergi ${ }^{8}$. Dalam kamus besar bahasa Indonesia, perkosaan berasal dari kata perkosa yang berarti menggagahi atau melanggar dengan kekerasan. Sedangkan pemerkosaan diartikan sebagai proses, cara, perbuatan perkosa atau melanggar dengan kekerasan ${ }^{9}$. Apabila merujuk pada ketentuan hukum pidana yang saat ini berlaku di Indonesia, maka pemaknaan perkosaan pada umumnya adalah sebagaimana yang termuat

5 Komnas Perempuan. 2017. Catatan Tahunan Tentang Kekerasan Terhadap Perempuan Tahun 2017, hlm 2.

6 Berdasarkan penelusuran terhadap Catatan Tahunan Tentang Kekerasan Terhadap Perempuan Tahun 2016-2014, Komnas Perempuan.

7 Komnas Perempuan. 2016. Catatan Tahunan Tentang Kekerasan Terhadap Perempuan Tahun 2015, hlm.14.

8 Hariyanto. 1997. Dampak Sosio-Psikologis Korban Tindak Pidana Perkosaan Terhadap Perempuan. Jogjakarta : Pusat Studi Perempuan Universitas Gajah Mada, hlm. 97.

9 Tim Prima Pena. Kamus Besar Bahasa Indonesia, Jakarta: Gitamedia Press, hlm. 453. dalam Pasal 285 KUHP, yang berbunyi: "Barang siapa dengan kekerasan atau ancaman kekerasan memaksa seorang wanita bersetubuh dengan dia di luar perkawinan, diancam karena melakukan perkosaan dengan pidana penjara paling lama dua belas tahun." 10

Ketentuan pidana tersebut merupakan suatu ketentuan hukum yang diadopsi dari kitab undang-undang hukum Belanda Wetboek van Strafrecht $(W v S)$, yang sempat diberlakukan di Belanda hingga akhirnya di amandemen. Sedangkan di Indonesia, ketentuan pidana tersebut masih diberlakukan bersamaan dengan evolusi dalam ketentuan pidana terkait kekerasan seksual. Dalam hal ini, maka dapat dikatakan bahwa telah terjadi kekosongan hukum di Indonesia terkait dengan tindak pidana perkosaan dalam rumah tangga. Namun, pada perkembangannya, pengaturan mengenai pemaksaan hubungan seksual terhadap pasangan yang berada dalam ikatan perkawinan ini kemudian termuat Pasal 46 jo Pasal 8 huruf a Undang-Undang Nomor 23 Tahun 2004 tentang Penghapusan Kekerasan Dalam Rumah Tangga (UU-PKDRT), yang menyebutkan sebagai berikut:

\section{Pasal 46}

Setiap orang yang melakukan perbuatan kekerasan seksual sebagaimana dimaksud dalam Pasal 8 huruf a dipidana dengan pidana penjara paling lama 12 (dua belas) tahun atau denda paling banyak Rp 36.000.000,00 (tiga puluh enam juta rupiah).

\section{Pasal 8}

Kekerasan seksual sebagaimana dimaksud dalam Pasal 5 huruf c meliputi:

a. pemaksaan hubungan seksual yang dilakukan terhadap orang yang menetap dalam lingkup rumah tangga tersebut;

10 Indonesia. Kitab Undang-Undang Hukum Pidana. 
b. Pemaksaan hubungan seksual terhadap salah seorang dalam lingkup rumah tangganya dengan orang lain untuk tujuan komersial dan/atau tujuan tertentu.

Dalam ketentuan pada pasal tersebut, tidak disebutkan secara eksplisit mengenai larangan bagi seorang suami (atau istri) melakukan pemaksaan untuk berhubungan seksual kepada pasangannya (marital rape), di mana subjek hukum yang termuat adalah larangan bagi setiap orang untuk tidak melakukan pemaksaan hubungan seksual terhadap orang yang menetap dalam lingkup rumah tangga, yang berarti memiliki makna lebih luas.

Isu perkosaan dalam rumah tangga dianggap sebagai suatu hal yang bersifat privat. Pemikiran tersebut di dukung dengan adanya budaya patriarki yang kental dalam masyarakat Indonesia. Selain itu, pembuktian terjadinya kekerasan seksual terhadap seseorang (biasanya wanita) yang dilakukan oleh suaminya, sulit untuk dibuktikan. Kepada seorang pelaku yang menggunakan kekerasan seksual untuk dapat melakukan hubungan seksual dengan pasangannya tidak dikenakan Pasal 46 UUPKDRT tersebut, melainkan pasal penganiayaan yang lebih mudah untuk dibuktikan unsur-unsurnya. Meskipun telah termuat dalam UUPKDRT, kriminalisasi terhadap kekerasan seksual kembali dituangkan dalam RUU-PKS namun dalam substansi ketentuan hukum yang berbeda. Inisasi tersebut menimbulkan pertentangan pendapat terkait ketentuan pidana yang berkemungkinan menjerat pelaku marital rape dalam RUU-PKS. Isu marital rape dalam RUU-PKS dapat dikatakan sebagai "old wine in a new bottle", yaitu suatu isu lama yang dikemas dalam konteks yang berbeda. Kebutuhan peran dari negara untuk ikut campur dalam ranah privat warga negaranya diperdebatkan. Adapun me- lihat dari pertentangan pendapat yang ada, Pasal 16 jo Pasal 8 RUU-PKS menunjukkan suatu kekaburan hukum dikarenakan masyrakat pada pihak kontra seolah belum mengetahui dengan jelas apa yang dimaksud dan dikehendaki dari pasal tersebut. Adapun rumusan masalah dalam penelitian ini antara lain:

a. Bagaimana perkembangan penerimaan unsur perkawinan dalam tindak pidana pemaksaan hubungan seksual (perkosaan) berdasarkan hukum pidana materiil di Indonesia?

b. Apa yang menjadi dasar teoritis penerimaan kriminalisasi perkosaan dalam rumah tangga (marital rape) berdasarkan Rancangan Undang-Undang Penghapusan Kekerasan Seksual?

Sedangkan tujuan penelitian adalah sebagai berikut:

a. Untuk mengetahui perkembangan penerimaan unsur perkawinan dalam tindak pidana pemaksaan hubungan seksual (perkosaan) berdasarkan hukum pidana materiil di Indonesia

b. Untuk mengetahui dasar teoritis penerimaan kriminalisasi perkosaan dalam rumah tangga (marital rape) berdasarkan Rancangan Undang-Undang Penghapusan Kekerasan Seksual

\section{METODE}

Penelitian ini adalah penelitian yuridisnormatif yang bersifat deskriptif analitis, dengan menggunakan pendekatan undangundang, pendekatan historis dan pendekatan konseptual. Penelitian ini menggunakan sumber berupa bahan hukum, antara lain; peraturan perundang-undangan, di antaranya Kitab Undang-Undang Hukum Pidana, Undang-Undang No. 23 Tahun 2004 tentang Penghapusan Kekerasan Dalam Rumah Tang- 
ga (UU-PKDRT) dan Rancangan UndangUndang Penghapusan Kekerasan Seksual (RUU-PKS), literatur, jurnal dan kamus hukum, serta bahan-bahan non-hukum yang memiliki keterkaitan dengan isu yang dibahas. Dalam pengumpulan bahan hukum, Peneliti menggunakan studi kepustakaan, yaitu dengan meneliti peraturan perundang-undangan dan literatur-literatur serta menginventarisir buku-buku yang mempunyai keterkaitan dengan permasalahan yang dibahas, yang kemudian diolah dan dianalisis untuk kemudian disusun secara logis dan sistematis agar diperoleh kesimpulan yang sesuai dengan tujuan penelitian.

\section{ANALISIS DAN PEMBAHASAN}

Perkembangan Penerimaan Unsur "Di Luar Perkawinan" Dalam Tindak Pidana Perkosaan Berdasarkan Pengaturan Hu-

\section{kum Pidana di Indonesia}

Pasal 285 KUHP berbunyi, "Barang siapa dengan kekerasan atau ancaman kekerasan memaksa seorang perempuan bersetubuh dengan dia di luar perkawinan, diancam karena melakukan perkosaan dengan pidana penjara paling lama dua belas tahun.”. Unsur-unsur yang terdapat dalam tindak pidana ini antara lain: dengan kekerasan atau ancaman kekerasan; memaksa wanita yang tidak terikat perkawinan dengan pelaku (bukan istrinya) untuk melakukan hubungan seksual $^{11}$. Oleh karena itu, pemaksaan hubungan seksual bukan merupakan suatu tindak pidana selama pihak yang lain terikat perkawinan dengan si pelaku.

11 Khalida Zia Istiqomah. 2014. Skripsi: Reformulasi Pengaturan Sanksi Tindak Pidana Perkosaan di Indonesia (Studi Perbandingan Hukum Pidana Positif dan Hukum Pidana Islam), Malang: Fakultas Hukum Universitas Brawijaya, hlm. 2.
Berdasarkan pengalaman sejarah bangsa, Indonesia menganut sistem hukum Eropa Kontinental sehingga menggunakan peraturan perundang-undangan sebagai sumber hukum utama, disamping sumber hukum lain yang juga diakui dan digunakan Salah satu sumber hukum yang digunakan untuk menentukan apakah perbuatan seseorang dapat atau tidak dapat dikatakan sebagai suatu tindak pidana adalah Kitab Undang-Undang Hukum Pidana (KUHP), atau yang dalam bahasa Belanda disebut sebagai Wetboek van Strafrecht $(W v S)$. Wvs adalah kitab undang-undang hukum pidana yang digunakan oleh Belanda yang kemudian diterapkan di Indonesia berdasarkan "asas konkordansi"12. Pada masa transisi kolonialisme dari Belanda ke Jepang sendiri, tidak banyak perubahan yang terjadi dalam hal ketentuan hukum pidana, dikarenakan masa penjajahan yang jauh lebih singkat sehingga hukum pidana yang telah ada masih diberlakukan selama tidak bertentangan dengan pemerintahan Jepang ${ }^{13}$. Setelah proklamasi dilaksanakan pun, untuk mencegah terjadinya kekosongan hukum, ketentuan hukum pada masa tersebut kemudian tetap digunakan dengan adanya Pasal II Ketentuan Peralihan Undang-Undang Dasar Republik Indonesia Tahun 1945 yang menyebutkan bahwa, "Segala peraturan perundang-undangan yang ada masih tetap berlaku selama belum diadakan yang baru menurut Undang-Undang Dasar ini." "14

Belanda datang ke Indonesia dengan mem-

12 Ahmad Bahiej. 2006, "Sejarah dan Problematika Hukum Pidana Materiel di Indonesia", Jurnal: Sosio-Religia. 5(2): 13.

13 Ibid, hlm. 7.

14 Indonesia. Undang-Undang Dasar Negara Republik Indonesia Tahun 1945. 
bawa misi 3G; Gold, Glory dan Gosphel ${ }^{15}$. Misi Gosphel (penyebaran agama kristen) menunjukkan bahwa agama kristen memiliki pengaruh terhadap Belanda. Penerimaan unsur "di luar perkawinan" pada ketentuan pidana perkosaan dalam WvS pada zaman dulu di pengaruhi oleh nilai dalam agama kristen yang menganggap adalah suatu kewajiban bagi istri untuk memenuhi kebutuhan suami. Sebagaimana disebutkan, . "Some have used passages like 1 Corinthians 7:1-5 and Ephesians 5:22 to claim that the Bible does not recognize marital rape and that wives must always consent to sex ${ }^{16}$ " Padahal anggapan bahwa kewajiban tersebut adalah alasan yang membenarkan paksaan hubungan seksual dalam ikatan suami-istri adalah misinterpretasi yang salah. "Using these passages in that way is a gross misinterpretation and misuse of the Word of God. ${ }^{17}$ ",

Muatan unsur "di luar perkawinan" yang termuat dalam Pasal 285 KUHP tersebut juga diterima di Indonesia karena anggapan bahwa perkosaan tidak mungkin terjadi dalam ikatan perkawinan karena pemenuhan kebutuhan seksual adalah suatu kewajiban bagi seorang istri. Kewajiban perempuan untuk patuh terhadap laki-laki merupakan suatu unsur dari sistem (budaya) patriarki. Keberadaan budaya patriarki sendiri diperkirakan sudah ada sejak zaman berburu dan mengumpulkan makanan (hunter-gatherers) dan masih berlanjut hingga masa agrikultur di mana ma-

15 Baiq L.S.W. "Wardhani. 2016. "Respon Postkolonial Terhadap Intensifikasi Pendidikan Kolonial di Afrika", Global dan Strategis. 10(1): 137

16 Compelling Truth Org. What Is A Biblical Perspective On Marital/Spousal Rape?. https:// www.compellingtruth.org/spousal-marital-rape. html, diakses pada 16 Agustus 2019.

17 Ibid. syarakat pada masa pra-historis tersebut sudah tidak lagi hidup secara nomaden sehingga menimbulkan suatu kebutuhan perlindungan dari laki-laki yang dianggap secara fisik lebih kuat ${ }^{18}$. Dalam budaya patriarki, seorang perempuan memiliki posisi yang lebih inferior dibandingkan laki-laki sehingga membatasi ruang gerak bagi seorang perempuan. Superioritas dari laki-laki tersebut semakin kuat dalam ranah rumah tangga, di mana anggota keluarga wajib patuh terhadap laki-laki yang bertindak sebagai kepala keluarga. Selain dari faktor tersebut, yang menjadi alasan pendukung penerimaan unsur "di luar perkawinan" sebagai unsur dari tindak pidana perkosaan adalah nilai dalam agama islam sebagai agama dengan penganut mayoritas. Salah satunya sebagaimana dimuat dalam QS. An-Nisa/4:34 yang secara tekstual dianggap menunjukkan bahwa suami memiliki kekuasaan mutlak terhadap istri ${ }^{19}$. Sehingga pemaksaan untuk berhubungan seksual yang dilakukan oleh suami dianggap bukan suatu bentuk perkosaan. Faktor-faktor tersebut menimbulkan munculnya faktor internal yang mendukung penerimaan unsur "di luar perkawinan" baik bagi pelaku maupun korban. Pelaku merasa bahwa perbuatannya bukan perbuatan yang salah, dan korban merasa ada hal-hal yang membenarkan perbuatan pelaku. Hal ini di tambah dengan kurangnya kesadaran diri

18 Anil Ananthaswamy dan Kate Douglass. 2018, The Origins of Sexism: How Men Came to Rule 12,000 Years Ago. https://www.newscientist.com/ article/mg23831740-400-the-origins-of-sexismhow-men-came-to-rule-12000-years-ago/, diakses pada 16 Agustus 2019.

19 Hasmila. 2017. Skripsi: Marital Rape (Pemaksaan Hubungan Seksual Suami Terhadap Istri) Perspektif Hukum Islam dan Undang-Undang Penghapusan Kekerasan Dalam Rumah Tangga, Makassar: Fakultas Syari'ah dan Hukum Universitas Islam Negeri Alauddin, hlm. 15. 
dari korban bahwa dalam ikatan perkawinan pun, ia masih memiliki hak asasi penuh atas tubuhnya. serta anggapan dari masyarakat pada umumnya bahwa urusan rumah tangga adalah urusan privat yang cukup diselesaikan secara internal.

Apabila merujuk pada Belanda sebagai negara yang membawa KUHP untuk kemudian diterapkan di Indonesia, amandemen WvS pada tahun 1991 telah menghapuskan unsur "di luar pernikahan" ${ }^{20}$, sehingga kriminalisasi terhadap pelaku perkosaan di mana antara pelaku dan korban terdapat ikatan perkawinan dilakukan. Sebagaimana disebutkan dalam Pasal $242 \mathrm{WvS}$ yang ditranslasi ke dalam bahasa Inggris oleh European Justice Training Network, "Any person who by an act of violence or any other act or by threat of violence or threat of any other act compels a person to submit to acts comprising or including sexual penetration of the body shall be guilty of rape and shall be liable to a term of imprisonment not exceeding twelve years or a fine of the fifth category. ${ }^{21}$ " Hal ini berbeda dengan ketentuan berdasarkan Pasal 285 KUHP yang belum mengakomodir perlindungan dan penegakan hak perempuan untuk tidak melakukan perbuatan yang tidak dikehendaki, termasuk dalam konteks pemaksaan hubungan seksual dalam ranah rumah tangga. Dibutuhkan kebijakan hukum pidana (criminal policy) yang merupakan bagian integral

20 National Sexual Rights Law and Policy Database. Netherlands: Marital Rape, http:// sexualrightsdatabase.org/static/country-420.html, diakses pada 16 Agustus 2019.

21 European Justice Training Network. 2014. Netherland Criminal Code English Translation,http://www.ejtn.eu/ PageFiles/6533/2014\%20seminars/Omsenie/ WetboekvanStrafrecht_ENG_PV.pdf, diakses pada 16 Agustus 2019. dari kebijakan sosial (social policy) sebagai usaha penanggulangan kejahatan melalui pembentukan undang-undang pidana sebagai bagian dari usaha perlindungan masyarakat ${ }^{22}$. Oleh karena itu, pada perkembangannya, muncul Undang-Undang Nomor 23 Tahun 2004 tentang Penghapusan Kekerasan Dalam Rumah Tangga (UU-PKDRT), di mana Pasal 46 jo. Pasal 8 huruf a menyebutkan sebagai berikut:

\section{Pasal 46}

Setiap orang yang melakukan perbuatan kekerasan seksual sebagaimana dimaksud dalam Pasal 8 huruf a dipidana dengan pidana penjara paling lama 12 (dua belas) tahun atau denda paling banyak Rp 36.000.000,00 (tiga puluh enam juta rupiah).

Pasal 8

Kekerasan seksual sebagaimana dimaksud dalam Pasal 5 huruf c meliputi:

a. pemaksaan hubungan seksual yang dilakukan terhadap orang yang menetap dalam lingkup rumah tangga tersebut;

b. pemaksaan hubungan seksual terhadap salah seorang dalam lingkup rumah tangganya dengan orang lain untuk tujuan komersial dan/atau tujuan tertentu. ${ }^{23}$

Dalam penjelasan Pasal 8 UU-PKDRT disebutkan bahwa bentuk kekerasan seksual adalah, "perbuatan berupa pemaksaan hubungan seksual, pemaksaan hubungan seksual dengan cara tidak wajar dan/atau tidak disukai, pemaksaan hubungan seksual dengan orang lain untuk bertujuan komersial dan/

22 Lilik Mulyadi. 2004. Kapita Selekta Hukum Pidana Kriminologi dan Victimologi. Jakarta: Djambatan, hlm. 30

23 Republik Indonesia, Undang-Undang No. 23 Tahun 2004 tentang Penghapusan Kekerasan Dalam Rumah Tangga, LN No. 95 Tahun 2004, TLN No. 4419. 
atau tujuan tertentu"24. Sebelum adanya UUPKDRT, tergolong sulit bagi seorang korban KDRT untuk mendapat keadilan dan perlindungan dikarenakan belum adanya payung hukum dan paradigma bahwa masalah privat tidak perlu mengikutsertakan intervensi pihak luar ${ }^{25}$. Mengutip dari Naskah Akademik RUU-PKS:

"Kasus perkosaan juga terjadi di dalam lingkup rumah tangga. Istri dalam hal ini termasuk pihak yang paling rentan mengalami perkosaan dalam perkawinan. Beberapa orang dan kelompok masyarakat memang terus menyangkal adanya perkosaan terhadap istri dalam perkawinan. Namun, sejumlah pengaduan yang disampaikan istri ke lembaga pendamping dan kepolisian mengaku bahwa mereka sering dipaksa oleh pasangan atau suami mereka untuk melakukan hubungan seksual. Bahkan tidak jarang, pasangan atau suami mereka melakukannya dengan cara-cara yang melukai secara fisik dan membahayakan kesehatan reproduksi." 26

Secara bahasa, marital rape diartikan sebagai "Rape committed by the person to whom the victim is married", yaitu perkosaan yang dilakukan oleh seseorang kepada korban

\section{Ibid.}

25 Kementerian Hukum dan Hak Asasi Manusia Republik Indonesia. Undang-Undang No. 23 Tahun 2004 Suatu Tantangan Menuju Sistem Hukum Yang Responsif Gender. http://ditjenpp. kemenkumham.go.id/hukum-pidana/652-undangundang-nomor-23-tahun-2004-suatu-tantanganmenuju-sistem-hukum-yang-responsif-gender. $\mathrm{html}$ ?fontstyle $=\mathrm{f}$-smaller, diakses pada 16 Agustus 2019.

26 Forum Pengada Layanan Komisi Nasional Anti Kekerasan Terhadap Perempuan. 2017. Naskah Akademik RUU tentang Penghapusan Kekerasan Seksual, https://drive.google.com/ file/d/1kpiDkdCjfSUgrbDqTgClU9CwR_izVokn/ view, diakses pada 16 Agustus 2019. yang sudah dinikahinya ${ }^{27}$. World Health Organization (WHO) telah mengklasifikasikan marital rape ke dalam jenis kekerasan seksual (sexual violence). Perbuatan tersebut dapat mempengaruhi kondisi psikologis dan fisik seorang wanita, termasuk alat reproduksinya. Inisiasi terkait penanggulangan masalah kekerasan seksual kini termuat dalam Rancangan Undang-Undang Penghapusan Kekerasan Seksual (RUU-PKS) yang mendefinisikan jenis kekerasan seksual lebih luas dan dalam ranah yang lebih beragam dibandingkan ketentuan hukum yang telah ada sebelumnya. Sebagaimana termuat dalam Pasal 16 Jo. Pasal 11 RUU-PKS yang berbunyi sebagai berikut: Pasal 11

(1)Setiap orang dilarang mealkukan Kekerasan Seksual

(2)Kekerasan seksual terdiri dari:
a. pelecehan seksual;
b. eksploitasi seksual;
c. pemaksaan kontrasepsi;
d. pemaksaan aborsi;
e. perkosaan;
f. pemaksaan perkawinan;
g. pemaksaan pelacuran;
h. perbudakan seksual; dan/atau
i. penyiksaan seksual.

(3)Kekerasan seksual sebagaimana dimaksud pada ayat (1) meliputi peristiwa kekerasan seksual dalam lingkup relasi personal, rumah tangga, relasi kerja, publik, dan situasi khusus lainnya

\section{Pasal 16}

Perkosaan sebagaimana dimaksud dalam Pasal 11 ayat (2) huruf e adalah kekerasan seksual yang dilakukan dengan bentuk kekerasan, ancaman kekerasan, atau tipu muslihat, atau

27 Oxford Dictionaries. Marital Rape. www. oxforddictionaries.com/definition/english/maritalrape. diakses pada 16 Agustus 2019. 
menggunakan kondisi seseorang yang tidak mampu memberikan persetujuan untuk melakukan hubungan seksual ${ }^{28}$

Jika membandingkan antara UU-PKDRT dengan RUU-PKS, terdapat beberapa perbedaan terkait isu marital rape dan kekerasan seksual secara umum. Pertama, mengenai pengertian jenis kekerasan seksual dalam RUU-PKS yang lebih luas yang belum diakui oleh hukum positif saat ini, salah satunya adalah keberadaan marital rape. Kedua, subjek yang dapat menjadi korban dalam pemaknaan kekerasan seksual. RUU-PKS memiliki cakupan yang lebih luas yang mana relasi personal tidak hanya terbatas pada ranah rumah tangga. Ketiga, mengenai ancaman pidana, di mana UU-PKDRT dalam konteks marital rape memiliki ancaman pidana berupa pidana penjara dengan minimal 3 tahun penjara dan 12 tahun penjara serta pidana ganti kerugian. Sedangkan RUU-PKS dalam konteks perkosaan sebagai kekerasan seksual secara umum memiliki ancaman pidana minimum dan maksimum yang diatur dalam Pasal 108 s.d. Pasal 115 RUU-PKS, di mana pidana pokok yang diancamkan memiliki kualifikasi tersendiri dan pidana tambahan yang beragam. Keempat, mengenai pengaturan pembuktian, di mana untuk hukum acara berdasarkan UU-PKS, terdapat alat bukti lain yang tidak ada dalam alat bukti hukum acara pidana umum, seperti surat keterangan psikolog, informasi yang disimpan secara elektronik, dan hasil pemeriksaan rekening bank. Kelima, penekanan yang ada dalam RUUPKS, di mana yang dikedepankan tidak hanya upaya represif melalui kemungkinan pidana yang tercantum, namun juga upaya preventif. RUU-PKS mencantumkan upaya pencega-

28 Indonesia. Rancangan Undang-Undang Penghapusan Kekerasan Seksual. han kekerasan seksual yang perlu dilakukan oleh negara, pemerintah, dan pemerintah daerah dalam beberapa pasal, termasuk pula peran masyarakat misalnya melalui penguatan kapasitas tentang penghapusan kekerasan seksual bagi lembaga/kelompok masyarkat, keagamaan, kepercayaan, dan adat. Sedangkan UU-PKDRT tidak mencantumkan muatan pencegahan sedemikian rupa.

\section{Dasar Yuridis dan Teoritis Penerimaan Kriminalisasi Pemaksaan Hubungan Sek- sual (Perkosaan) Dalam Rumah Tangga (Marital Rape)}

Indonesia sebagai penganut sistem hukum civil law menjunjung tinggi keberadaan asas legalitas yang mengharuskan adanya ketentuan pidana terlebih dahulu sebelum seseorang dapat dipidanakan. Perkembangan hukum yang ada telah menunjukkan bahwa persepsi pemaksaan hubungan seksual hanya dapat terjadi di luar perkawinan kini telah bergeser. Di Indonesia, pemikiran untuk memaksimalkan perlindungan hak telah berkembang, termasuk dalam hal pemaksaan hubungan seksual dalam rumah tangga. Sebagaimana telah dipaparkan bahwa UU-PKDRT telah memuat larangan dalam pemaksaan hubungan seksual (yang masuk dalam lingkup kekerasan seksual) dalam rumah tangga. Pada perkembangannya, RUU-PKS memuat tidak hanya larangan sedemikian rupa, namun juga hukum acara berbeda dengan hukum acara pidana konvensional. Dalam melaksanakan hukum acara pidana untuk tindak pidana perdasarkan RUU-PKS, penegak hukum seperti hakim disebutkan dilarang untuk menanyakan hal-hal bersifat menyudutkan. Merujuk pada hal tersebut, maka dapat dikatakan bahwa ada inovasi yang coba dilakukan oleh negara untuk mewujudkan sistem peradilan pidana yang lebih baik dalam menghadapi kasus 
yang memang membutuhkan penerapan hukum acara yang khusus.

Sebagaimana telah disebutkan bahwa marital rape adalah suatu pemaksaan hubungan seksual di mana antara pelaku dan korban terikat hubungan perkawinan. Di Indonesia, hal tersebut didukung dengan sistem patriarki yang hidup dalam masyarakat, baik atas dasar budaya, maupun pengaruh perspektif agama. Menurut Alfian Rokhmansyah dalam bukunya yang berjudul Pengantar Gender dan Feminisme, patriarki berasal dari kata 'patriarkat', yaitu struktur yang menempatkan peran lakilaki sebagai penguasa tunggal dan sentral sehingga mendominasi kebudayaan masyarakat yang menyebabkan kesenjangan dan ketidakadilan gender yang mempengaruhi hingga ke berbagai aspek. Perempuan hanya memiliki sedikit pengaruh dan diletakkan pada posisi subordinat atau inferior diharuskan patuh kepada laki-laki ${ }^{29}$. Masyarakat yang terbiasa dengan budaya patriarki memandang bahwa Indonesia sebagai negara yang menganut nilai ketimuran tidak perlu mengatur urusan hubungan privat sebagaimana dimaksud. Disebutkan oleh Prof. Dr. Nurul Ilmi Idrus, M.Sc., Ph.D. yang dikutip dalam artikel berjudul Marital Rape, Paradigma Masyarakat dan Hukum Islam, marital rape merupakan suatu konsep yang tidak dapat dimuat dalam undang-undang Indonesia karena tidak sesuai dengan nilai dalam masyarakat karena perkawinan adalah ikatan lahir batin sehingga masing-masing pihak dianggap tau hak dan

29 Alfian Rokhmansyah. 2013. Pengantar Gender Dan Feminisme, dalam Menyoroti Budaya Patriarki Di Indonesia, dalam Ade Irma Sakina dan Dessy Hasanah Siti A. "Menyoroti Budaya Patriarki di Indonesia". Jurnal: Social Work Journal. 7(1): 72. kewajiban $^{30}$. Dalam hal ini, maka Penulis akan memaparkan pertimbangan teoritis dan yuridis mengenai penerimaan kriminalisasi pemaksaan hubungan seksual dalam rumah tangga:

\section{Bentuk Perlindungan Kejahatan ter- hadap Wanita Dalam Rumah Tangga Berdasarkan Teori Critical Feminism Criminology}

Seiring dengan berkembangnya pemikiran tentang hak, termasuk hak wanita sebagai pihak yang rentan menjadi korban dalam ranah apapun, maka berkembang pula makna perkosaan yang lebih luas. Tidak dapat dipungkiri bahwa pergerakan wanita yang menginginkan kesetaraan hak asasi manusia terlepas dari gender yang melekat pada dirinya, mempengaruhi perkembangan makna perkosaan ini. Perspektif Amerika Serikat di masa lalu, seorang pria dianggap tidak melanggar hukum apabila memaksakan keinginan untuk berhubungan seksual dengan istrinya. Justifikasinya adalah:Pandangan bahwa hubungan antara suami dan istri didasarkan pada "contract of marriage" yang memberikan "right to sex" (hak untuk berhubungan seksual) yang harus dipenuhi oleh istri karena istri dianggap telah memberikan persetujuan (consent) dan menyetujui "contract of marriage" tersebut sejak awal, (2) pandangan lama bahwa istri adalah "hak milik" suami sehingga seorang suami dianggap dapat melakukan apa saja yang dimau, (3) kepentingan public yang menginkan keserasian dan menghargai terhadap hubungan pernikahan

30 Nurul Ilmi Idrus. 1999. Marital Rape: Kekerasan Seksual dalam Perkawinan. Yogyakarta: PDK UGM, hlm. 3, dalam Vienna Novia Lurizha Adza. Marital Rape, Paradigma Masyarakat, dan Hukum Islam, https://www.academia.edu/15551438/ Marital_Rape_Paradigma_Masyarakat_dan_ Hukum_Islam, diakses pada 16 Agustus 2019. 
sehingga negara tidak diperkenankan untuk melakukan intervensi. Perkosaan pada umumnya dan dalam konteks marital rape pada dasarnya memiliki makna yang sama, yaitu memberikan perlindungan kepada korban wanita, di mana yang membedakan adalah dalam marital rape, korban wanita tersebut memiliki ikatan perkawinan dengan pelaku ${ }^{31}$.

Apabila merujuk pada teori critical feminism criminology, disebutkan bahwa pembedaan antara perempuan dan laki-laki mengakibatkan timbulnya ketidaksetaraan gender dalam suatu masyarakat sehingga terjadi eksploitasi terhadap perempuan ${ }^{32}$. Perempuan dalam ranah rumah tangga atau sebatas inmates (tinggal dalam satu atap yang sama tanpa terikat perkawinan) memiliki kecenderungan menjadi korban berulang karena seringkali menjadi korban kekerasan termasuk perkosaan dalam hubungan yang terikat perkawinan. Kejahatan oleh orang terdekat justru lebih sering terjadi dibandingkan yang dilakukan oleh orang asing. Kelompok critical feminist menentang pandangan bahwa rumah adalah tempat yang aman bagi perempuan $^{33}$. Selain itu, terdapat kegagalan dalam menjelaskan keadaan perempuan sebagai korban dalam sistem peradilan pidana. Krimino-

31 Deborah C. England. The History of Marital Rape, https://www.criminaldefenselawyer.com/ resources/criminal-defense/crime-penalties/ marital-rape.htm, diakses pada 22 November 2019.

32 Larry J. Siegel. 2011. Criminology: The Core, Forth Edition. USA: Wadsworth Publishing, p.. 212.

33 Pamela Ugwudike. 2015. An Introduction to Critical Criminolog, Inggris: Policy Press, https:// books.google.co.id/books?id=st4aBwAAQBAJ\& printsec $=$ frontcover $\& \mathrm{dq}=$ critical + feminism + crim inology+theory\&hl=en\&sa $=$ X\&ved $=0$ ahUKEwi hjP2iqLHiAhWHpI8KHaANA2oQ6AEIXjAJ\#v $=$ onepage $\& \mathrm{q}=$ feminis $\& \mathrm{f}=$ false, diakses pada 16 Agustus 2019, nomor halaman tidak dicantumkan. $\log$ feminist mencoba mengembangkan pandangan viktimologi radikal untuk menentang konsep "victim precipitation" 34 yang mengakibatkan suatu keadaan di mana korban (perempuan) cenderung dipersalahkan. Contohnya dalam kasus perkosaan dan kekerasan domestik (dalam rumah tangga), perempuan dianggap memiliki standar perilaku yang dianggap seharusnya dilakukan, seperti kewajiban untuk patuh terhadap laki-laki (suaminya), sehingga dalam hal ini, ada atau tidaknya consent dalam melakukan hubungan seksual tidak diperhitungkan. Feminist radikal menginginkan pemerintah untuk memberikan atensi terhadap kebijakan untuk keadaan yang sedemikian rupa.

\section{Pencegahan Berdasarkan Tujuan Teori Pemidanaan Detterence}

Jika berbicara mengenai hukum pidana, maka rasanya tidak salah apabila sebagian besar masyarakat memiliki pandangan bahwa hukum pidana adalah sebagai bentuk pembalasan atas perbuatan yang telah dilakukan oleh seseorang, mengingat bahwa pemikiran lama mengenai tujuan pemidanaan adalah teori absolut di mana pidana digunakan sebagai alat untuk melakukan pembalasan terhadap pelaku yang telah melakukan tindak pidana. Menurut teori ini, dasar hukuman harus dicari dari kejahatan itu sendiri, karena

34 "Victim Precipitation" adalah suatu teori kriminologi yang menganalisa interaksi korban dan pelaku yang kemudian berkemungkinan menimbulkan kejahatan yang dilakukan oleh pelaku tersebut. Korban dianggap berpartisipasi dalam kejahatan sehingga korban dianggap sebagai 'pelaku pertama' yang memprovokasi pelaku kejahatan untuk berbuat sedimikian rupa. (Disadur dari Study.Com, Victim Precipitation: Definition \& Theory, https://study.com/academy/ lesson/victim-precipitation-definition-theory.html, diakses pada 16 Agustus 2019. 
kejahatan itu telah menimbulkan penderitaan bagi orang lain, sebagai imbalannya (vergelding) si pelaku harus diberi penderitaan ${ }^{35}$. $\mathrm{Pa}-$ dahal pada perkembangannya, hukum pidana melalui ketentuan pidananya tidak hanya ditujukan sebagai pembalasan atas perbuatan yang telah dilakukan, namun dapat pula dimaksudkan sebagai bentuk pencegahan (deterrence), baik secara khusus (specific deterence) dan umum (general deterrence), untuk menimbulkan manfaat yaitu melindungi masyaraka $^{36}$. Dasar pembenaran pidana terletak pada tujuannya adalah untuk mengurangi frekuensi kejahatan. Pidana dijatuhkan bukan karena orang membuat kejahatan, melainkan supaya orang jangan melakukan kejahatan. Sehingga teori ini sering juga disebut teori tujuan (utilitarian theory) ${ }^{37}$. Pandangan untilitarian melihat pemidanaan dari segi manfaat atau kegunaannya dimana yang dilihat adalah situasi atau keadaan yang ingin dihasilkan dengan dijatuhkannya pidana itu. Di satu pihak, pemidanaan dimaksudkan untuk memperbaiki sikap atau tingkah laku terpidana dan di pihak lain pemidanaan itu juga dimaksudkan untuk mencegah orang lain dari kemungkinan melakukan perbuatan yang serupa $^{38}$. Oleh karena itu, jika merujuk pada teori tujuan pemidanaan ini, maka yang menjadi poin penting bukanlah pembalasan melalui sanksi pidana, namun upaya untuk menimbulkan kesadaran bagi semua pihak bahwa kekerasan seksual, apapun bentuknya dan

35 Leden Marpaung. 2009. Asas-Teori-Praktek Hukum Pidana. Jakarta : Sinar Grafika, hlm 105.

36 Ibid, hlm 106.

37 Dwidja Priyanto. 2009. Sistem Pelaksanaan Pidana Penjara Di Indonesia. Bandung: PT. Rafika Aditama, hlm 26.

38 Herbert L. Packer. 1968. The Limits of The Criminal Sanction. USA: Stanford University Press, p. 9. dalam ranah apapun terjadinya, bukanlah sesuatu yang dapat dibenarkan., karena penyelesaian melalui jalur pidana pada akhirnya hanyalah suatu alternatif yang menjadi ultimum remedium bagi para pihak yang berperkara. Selain itu, penerimaan kriminalisasi marital rape sebagai upaya pencegahan juga termuat dalam The Declaration on The Elimination of Violence Against Women and Elimination of Violence Against Women in ASEAN yang akan dibahas pada sub-bab selanjutnya.

\section{Realisasi Perlindungan Hak Asasi Manusai Berdasarkan Undang-Un- dang Dasar Negara Republik Indonesia Tahun 1945 dan Konvensi serta Perjan- jian Internasional}

Intervensi negara dalam menetapkan sanksi pidana atas kasus rumah tangga yang bersifat perdata pada kehadirannya menimbulkan pro dan kontra dalam masyarakat. Padahal kekerasan dalam rumah tangga merupakan suatu perbuatan yang melanggar hak asasi atas tubuh seseorang. Dalam Pasal 28G Undang-Undang Dasar Negara Republik Indonesia Tahun 1945 disebutkan, "Setiap orang berhak atas perlindungan diri pribadi, keluarga, kehormatan, martabat, dan harta benda yang di bawah kekuasaanya, serta berhak atas rasa aman dan perlindungan dari ancaman ketakutan untuk berbuat atau tidak berbuat sesuatu yang merupakan hak asasi." Pemenuhan hak sedemikian rupa ini merupakan tanggung jawab dari dengan keberadaan Pasal 28I ayat (4) yang menyebutkan, "Perlindungan, pemajuan, penegakan, dan pemenuhan hak asasi manusia adalah tanggung jawab negara, terutama pemerintah,".

Adapun lebih luas dari tema marital rape sendiri, pembentukan RUU-PKS merupakan komitmen Indonesia atas keikutsertaannya 
dalam deklarasi dan perjanjian Internasional antara lain mengenai perlindungan terhadap wanita, contohnya dalam The Declaration on The Elimination of Violence Against Women and Elimination of Violence Against Women in ASEAN yang dibentuk oleh The ASEAN Commission on the Promotion and Protection of the Rights of Women (ACWC) untuk memperkuat upaya ASEAN dalam perlindungan hak perempuan yang diususn di Jakarta pada 13 juni $2004^{39}$. Setiap negara yang terlibat, termasuk Indonesia, sudah semestinya berusaha keras untuk mengimplementasikan dan berkomitmenuntuk menghapuskan kekerasan terhadap wanita, di mana salah satunya adalah dengan membentuk dan menegakkan aturan (undang-undang) yang diterapkan untuk mencegah kekerasan terhadap wanita, memaksimalkan perlindungan, membantu tahap penyembuhan, pemulihan, dan reintegrasi korban (wanita), termasuk upaya investigasi, prosekusi, pemidanaan, rehabilitasi yang tepat bagi pelaku, serta upaya pencegahan terjadinya re-viktimisasi terhadap wanita dan perempuan yang menjadi korban kekerasan, baik dalam lingkungan rumah, lingkungan kerja, masyarakat, bahkan dalam lingkungan penahanan (lapas) sekalipun ${ }^{40}$.

39 Kementrian Luar Negeri Republik Indonesia. 2019. Masyarakat Sosial Budaya ASEAN, https://kemlu.go.id/ portal/id/read/115/halaman_list_lainnya/ masyarakat-sosial-budaya-asean, diakses pada 21 November 2019.

40 Dalam Article 4 The Declaration on The Elimination of Violence Against Women and Elimination of Violence Against Women in ASEAN, disebutkan, "To enact and, where necessary, reinforce or amend domestic legislation to prevent violence against women, to enhance the protection, healing, recovery and reintegration of victims/survivors, including measures to investigate, prosecute, punish and where appropriate rehabilitate perpetrators, and prevent re-victimisation of
Marital rape dapat diartikan sebagai tindakan seksual apapun yang tidak diinginkan, yang dilakukan oleh pasangan yang dilakukan tanpa persetujuan (consent) pihak lainnya. Perilaku seksual ini dilakukan dengan paksaan, ancaman paksaan, atau intimidasi di mana korban tidak memberikan persetujuan, seperti bersetubuh, anal, dan tindakan lain yang dianggap merendahkan, memalukan, menyakitkan, dan tidak diinginkan oleh korban $^{41}$. Perempuan yang mengalami pemaksaan untuk berhubungan seksual dalam ranah perkawinan biasanya tidak berani untuk mengadu, melaporkan, ataupun membela diri, karena takut mendapat pandangan buruk terhadap dirinya ${ }^{42}$. Paradigma yang ada menganggap bahwa urusan rumah tangga semestinya menjadi urusan privat antara pihak terkait. Hemat penulis, pandangan sedemikian rupa justru merupakan bentuk pembiaran diskriminasi gender yang terjadi secara default akibat penanaman nilai yang kurang tepat. Pemaksaan hubungan seksual dalam rumah tangga seharusnya tidak dibenarkan, bahkan dalam perspektif agama islam sekalipun, mengingat perilaku kekerasan seksual suami terhadap istri masuk dalam kategori hukum pidana qishas pencederaan (penganiayaan) dan tidak mencerminkan adanya sikap saling

women and girls subjected to any form of violence, whether in the home, the workplace, the community or society or in custody."

41 Milda Marlia. 2007. Marital Rape: Kekerasan Seksual Terhadap Istri. Yogyakarta: LKIS Pelangi Aksara, hlm, 12.

42 Komnas Perempuan. 2018. Miskonsepsi terhadap RUUPenghapusan Kekerasan Seksual, Perspektif Gender, dan Feminisme, https://www. komnasperempuan.go.id/read-news-miskonsepsiterhadap-ruupenghapusan-kekerasan-seksualperspektif-gender-dan-feminisme, diakses pada 16 Agustus 2019. 
menghormati hak dan kewajiban antara suami dan istri yang menjadi wujud rumah tangga sakinah yang didasarkan pada mawadah dan rahmah $^{43}$.

\section{PENUTUP}

\section{Kesimpulan}

a. Pada awalnya hukum pidana di Indonesia tidak memaknai pemaksaan hubungan seksual pada korban dan pelaku yang memiliki ikatan perkawinan sebagai tindak pidana perkosaan sebagaimana disebutkan dalam Pasal 284 KUHP. Pada perkembangannya, muatan mengenai pemaksaan hubungan seksual sebagai tindak pidana masuk kedalam substansi Pasal 46 jo. Pasal 8 huruf a UU-PKDRT yaitu sebagai suatu bentuk kekerasan seksual. Namun keberadaan UU-PKDRT dianggap masih belum cukup memadai sehingga disusunlah UU-PKS, yang memiliki beberapa terobosan dalam menanggulangi tindak pidana terkait kekerasan seksual.

b. Ada beberapa alasan mengapa kriminalisasi marital rape dapat diterima, (1) didasarkan pada teori critical feminism criminology, berkembangnya pemikiran feminist yang mengakibatkan bergesernya perspektif makna perkosaan yang menganggap perempuan harus memenuhi "right to sex" suami akibat adanya contract of marriage yang dianggap telah disepakati oleh istri dan pandangan bahwa wanita adalah "hak milik" (property) suami. Wanita bahkan seringkali menjadi korban kekerasan, termasuk perkosaan dalam ranah rumah tanga. (2) Sanksi pidana dalam kriminalisasi marital rape yang dilakukan bukan didasarkan pada pemikiran pemidanaan lama yaitu sebagai bentuk pembalasan, namun digunakan sebagai bentuk perlindungan dan pemidanaan yang didasarkan pada teori deterrence (pencegahan) bagi korban dan masyarakat secara luas, (3) UUD sebagai konstitusi negara, dalam Pasal 28G UUD RI 1945 menyebutkan bahwa setiap warga negara memiliki hak untuk mendapat perlindungan diri, martabat dan perlindungan ancaman ketakutan untuk berbuat atau tidak berbuat seusatu. Intervensi negara sendiri diwajibkan dengan keberadaan Pasal 28I ayat 4 yang menyebutkan bahwa penegakan perlindungan dan pemenuhan hak asasi adalah tanggungjawab dari negara.

\section{Saran}

Mengingat bahwa nilai patriarki di Indonesia yang menganggap bahwa seorang perempuan (istri) seharusnya tunduk kepada lakilaki (suami) maka dibutuhkan suatu upaya untuk menciptakan paradigma bahwa hubungan suami-istri adalah hubungan koordinatif yang saling menghargai hak dan kewajiban satu dengan yang lain. Kriminalisasi atas marital rape sebagai bentuk intervensi dari negara dalam hubungan privat warga negara merupakan contoh perkembangan pemikiran hukum dalam ranah penegakan hak asasi manusia dan bentuk komitmen kewajiban negara untuk memberikan perlindungan atas harkat dan martabat setiap orang. Oleh karena itu, ketentuan kriminalisasi atas pemaksaan hubungan seksual dalam rumah tangga (marital rape) sebagaimana tertuang dalam RUUPKS sudah tepat dilakukan dan sudah semestinya disahkan sebagai undang-undang yang berlaku. Adapun apabila kemudian rancangan undang-undang ini disahkan, maka negara, melalui pemerintah bersama LSM yang me- 
miliki visi-misi terkait, perlu mengadakan edukasi dan sosialisasi yang tepat guna untuk meningkatkan sensitifitas gender dan kesadaran atas isu diskriminasi gender yang terjadi, baik terhadap masyarakat maupun penegak hukum.

\section{BIBLIOGRAFI}

Adza, Vienna Novia Lurizha. Marital Rape, Paradigma Masyarakat, dan Hukum Islam, https://www.academia. edu/15551438/marital_rape_paradigma_ masyarakat_dan_hukum_islam

Ananthaswamy, Anil. Kate Douglass. 2018. The Origins of Sexism: How Men Came to Rule 12,000 Years Ago, https://www. newscientist.com/article/mg23831740400-the-origins-of-sexism-how-mencame-to-rule-12000-years-ago/.

Bahiej, Ahmad. 2006. "Sejarah dan Problematika Hukum Pidana Materiel di Indonesia”. Jurnal: Sosio-Religia. 5(2): 13.

CNN Indonesia, 2019, Pemerintah Targetakn RUU-PKS Disahkan Agustus 2019, https://www.cnnindonesia.com/nasional/20190222200631-20-371945/pemerintah-targetkan-ruu-pks-disahkan-agustus-2019.

Compelling Truth. What Is A Biblical Perspective On Marital/Spousal Rape?, https://www.compellingtruth.org/spousal-marital-rape.html.

England, Deborah C., The History of Marital Rape, https://www.criminaldefenselawyer.com/resources/criminal-defense/ crime-penalties/marital-rape.htm, diakses pada 22 November 2019.

European Justice Training Network. 2014. Netherland Criminal Code English Translation, http://www.ejtn.eu/pagefiles/6533/2014\%20seminars/omsenie/ wetboekvanstrafrecht_eng_pv.pdf.

Forum Pengada Layanan Komisi Nasional Anti Kekerasan Terhadap Perempuan. 2017. Naskah Akademik RUU tentang Penghapusan Kekerasan Seksual, https://drive.google.com/file/ d/1kpiDkdCjfSUgrbDqTgClU9CwR_izVokn/view.

Gunarto, Marcus Priyo. Sikap Memidana Yang Berorientasi Pada Tujuan Pemidanaan. https://media.neliti.com/media/ publications/40559-ID-sikap-memidanayang-berorientasi-pada-tujuan-pemidanaan.pdf, diakses pada 21 November

Hariyanto. 1997. Dampak Sosio Psikologis Korban Tindak Pidana Perkosaan Terhadap Perempuan. Jogjakarta : Pusat Studi Perempuan Universitas Gajah Mada.

Hasmila. 2017. Skripsi: Marital Rape (Pemaksaan Hubungan Seksual Suami Terhadap Istri) Perspektif Hukum Islam dan Undang-Undang Penghapusan Kekerasan Dalam Rumah Tangga. Makassar: Fakultas Syari'ah dan Hukum Universitas Islam Negeri Alauddin..

Istiqomah, Khalida Zia. 2014. Skripsi: Reformulasi Pengaturan Sanksi Tindak Pidana Perkosaan di Indonesia (Studi Perbandingan Hukum Pidana Positif dan Hukum Pidana Islam). Malang: Fakultas Hukum Universitas Brawijaya.

Kementerian Hukum dan Hak Asasi Manusia Republik Indonesia, Undang-Undang No. 23 Tahun 2004 Suatu Tantangan Menuju Sistem Hukum Yang Responsif Gender, http://ditjenpp.kemenkumham.go.id/hukum-pidana/652-undang-undang-nomor23-tahun-2004-suatu-tantangan-menujusistem-hukum-yang-responsif-gender. html? fontstyle $=$ f-smaller.

Kementrian Luar Negeri Republik Indonesia, 
2019, Masyarakat Sosial Budaya ASEAN, https://kemlu.go.id/portal/id/read/115/ halaman_list_lainnya/masyarakat-sosialbudaya-asean, diakses pada 21 November 2019.

Komnas Perempuan. 2016. Catatan Tahunan Tentang Kekerasan Terhadap Perempuan Tahun 2015, https://www.komnasperempuan.go.id/file/pdf_file/catatan\%20tahunan/14.pp5_catahu\%202016.pdf.

Komnas Perempuan. 2017. Catatan Tahunan Tentang Kekerasan Terhadap Perempuan Tahun 2017, https://www.komnasperempuan.go.id/read-news-catatan-tahunankekerasan-terhadap-perempuan-2017.

Komnas Perempuan. 2018. Catatan Tahunan Tentang Kekerasan Terhadap Perempuan 2017, https://www.komnasperempuan.go.id/file/pdf_file/2018/publikasi/ catatan\%20tahunan\%20kekerasan\%20 terhadap\%20perempuan\%202018.pdf.

Komnas Perempuan. 2018,.Miskonsepsi terhadap RUUPenghapusan Kekerasan Seksual, Perspektif Gender, dan Feminisme, https://www.komnasperempuan.go.id/ read-news-miskonsepsi-terhadap-ruupenghapusan-kekerasan-seksual-perspektif-gender-dan-feminisme.

Komnas Perempuan. 2019. Catatan Tahunan Tentang Kekerasan Terhadap Perempuan Tahun 2018, https://www.komnasperempuan.go.id/file/catatan\%20tahunan $\% 20$ kekerasan $\% 20$ terhadap $\% 20$ perempuan\%202019.pdf.

Marlia, Milda. 2007. Marital Rape: Kekerasan Seksual Terhadap Istri. Yogyakarta: LKIS Pelangi Aksara.

Marpaung, Leden. 2009. Asas-Teori-Praktek Hukum Pidana. Jakarta: Sinar Grafika.

Mulyadi, Lilik. 2004 Kapita Selekta Hukum Pidana Kriminologi dan Viktimologi, Ja- karta: Djambatan.

National Sexual Rights Law and Policy Database, Netherlands: Marital Rape, http:// sexualrightsdatabase.org/static/country-420.html.

Oxford Dictionaries. Marital Rape, www.oxforddictionaries.com/definition/english/ marital-rape.

Packer, Herbert L. 1968. The Limits of The Criminal Sanction. USA: Stanford University Press.

Priyanto, Dwidja. 2009. Sistem Pelaksanaan Pidana Penjara Di Indonesia. Bandung: PT. Rafika Aditama.

Riana, Friski. 2018. Darurat Kekerasan Seksual dan Pembahasan RUU-PKS yang Lambat, https://nasional.tempo.co/ read/1149125/darurat-kekerasan-seksual-dan-pembahasan-RUU-PKS-yanglambat.

Siegel, Larry J. 2011. Criminology: The Core. Fourth Edition. California: Wadsworth Publishing.

Study.Com, Victim Precipitation: Definition \& Theory. https://study.com/academy/ lesson/victim-precipitation-definitiontheory.html.

Sakina, Ade Irma dan A, Dessy Hasanah Siti. 2017. "Menyoroti Budaya Patriarki di Indonesia". Jurnal: Social Work Journal. $7(1): 72$

Swartz, Nico P and Danga, Annah M. 2015. "Is A Husband Criminally Liable For Raping His Wife? A Comparative Analysis". Jurnal: International Journal of Academic Research and Reflection. 3(3).

Tim Prima Pena. Kamus Besar Bahasa Indonesia. Jakarta: Gitamedia Press.

Ugwudike, Pamela. 2015. An Introduction to Critical Criminology. Inggris: Policy 
Press.

Wardhani, Baiq L.S.W. 2016. "Respon Poskolonial terhadap Intensifikasi Pendidikan Kolonial di Afrika". Global dan Strategis, 10(1):137.

\section{Konvensi Internasional}

ASEAN, The Declaration on The Elimination of Violence Against Women and Elimination of Violence Against Women in ASE$A N$

\section{Peraturan Perundang-Undangan}

Indonesia, Undang-Undang Dasar Negara Republik Indonesia Tahun 1945

Indonesia, Kitab Undang-Undang Hukum Pidana
Indonesia, Undang-Undang No. 23 Tahun 2004 tentang Penghapusan Kekerasan Dalam Rumah Tangga, LN No. 95 Tahun 2004, TLN No. 4419

Indonesia, Rancangan Undang-Undang tentang Penghapusan Kekerasan Seksual 